\title{
CENTURY OF RESEARCH ON PROPERTY CYCLES: A LITERATURE REVIEW
}

\author{
Arvydas JADEVICIUS a,*, Brian SLOAN b, Andrew BROWN b \\ a School of Real Estate and Land Management, Royal Agricultural University, Cirencester GL7 6JS, UK \\ $b$ School of Engineering and the Built Environment, Edinburgh Napier University, Edinburgh \\ EH10 5DT, UK
}

Received 23 December 2014; accepted 3 May 2016

\begin{abstract}
The existence of cycles in building and property, has grown to have significant importance in the UK and internationally; whereas property markets have been characterised by boom and bust cycles with a negative impact on the national economies. As a result, property cycles became a popular research topic amongst property professionals and scholars, with a greater understanding of the cyclical behaviour of the property market being seen as a major guide to the financial success (failure) of property investments. Consequently, considerable literature has accumulated over the years on the subject. This paper provides a review of this literature, mostly written in the UK and US, with international insights on the subject. This paper reviews research on the subject chronologically over a one hundred-year period. The study is designed to provide readers with a historical overview of Property Cycles research by emphasising the underlying theme which dominated a particular period of this research, as well as indicating methods, data analysis techniques employed and outcomes of these studies. Its ai is to put more clarity on the subject, as well as help to navigate anyone interested in Property Cycles through a considerable amount of research which has accumulated over the last century.
\end{abstract}

KEYWORDS: Cycle; Literature; Property; Research; Review

\section{INTRODUCTION}

The nature, development, and reasons behind property cycles have been researched for more than a century (Mangoldt 1907; Hoyt 1933; Hakfoort 1992; RICS 1993; Barras 2009; Reed, Wu 2010; Grover, R., Grover, C. 2013, 2014). According to Rottke and Wernecke (2002: 3) 'in the US research on property cycles began as early as the 1930s (...) The number of publications rose rapidly at the beginning of the 1980s (...) Up to now in the US and the UK, cycle research papers have increased enormously both in terms of quantity and quality'. As Barras (2009) observed, the situation changed particularly after the Great Depression when academics and professionals became determined to find ways to prevent the recurrence of such dramatic events in the future. Therefore, they began to focus their attention on investment and building, as the most volatile element of the aggregate economic activity.

* Corresponding author. E-mail: a.jadevicius@gmail.com
As a result, a considerable amount of literature has accumulated on the subject. To illustrate the interest property cycles generated, Roulac et al. (2013) collected and analysed so called 'Estate Cycles Research' (RECR) studies presented at the major real estate conferences around the world stating from the early 1990s. According to their estimates, there were 16,000 property cycle papers submitted over the last two decades. The number of papers has grown exponentially since, outpacing any other real estate research subject.

This paper, therefore, provides a review of this literature. The reviewed literature was mostly written in the UK and US, with other international insights on the subject, and includes contributions from both academics and property practitioners. The objectives are to provide a guide to the literature on property cycles, to put more clarity on the subject as well as help to navigate anyone interested on property cycles through a considerable amount of research, which has accumulated over the last century. The current review is not 
designed to be a critical review of the subject, but rather a catalogue containing major papers on the subject.

The paper is organised as follows. The next section reviews the early studies on the subject which emerged in the early twentieth century, following the section on the property cycles literature of the post-war period. The subsequent section discusses post-1970s crash and post-1990s crash studies. The final section outlines the modern property cycle studies. The concluding remarks summarise the discussion and present key findings.

\section{MAIN CONTRIBUTION}

This paper reviews the main publications on property cycles published over the last century. Its main contribution to an already existing work on the topic is that it navigates reader throughout five time periods, concentrating on research topics, methods, and data analysis techniques employed and the outcomes of these studies. The contribution this study makes is that it places more clarity on the subject, as well as helps to navigate anyone interested on property cycles throughout a considerable amount of research chronologically.

Aside this current study, a few significant/ critical surveys were published on property cycles. RICS (1993) produced a comprehensive review on the subject. The RICS's study covered two broad areas. One, which was more descriptive, documented incidence of property cycles in different property markets. Here, the study examined literature on cycles' duration, severity and their links with economic and business cycles. The other, more empirical, section was concerned with the econometric analysis of property cycles. The study also offered a definition of property cycles (which is now generally accepted within the property community). According to the RISC (ibid., p. 3), "property cycles are recurrent but irregular fluctuations in performance as measured by fluctuations of real total return about its trend'.

More recently, and to a greater extent, Barras (2009) has provided us with his take on the subject. Barras' extensive discussion covered a wealth of literature on the theories related to property and building cycles: a commentary on building investment as a driver of lung-run growth; cycles as impetus to growth; a so called 'family of building cycles' and their importance; transmission of market cycles; speculative bubbles; integration of property and capital markets; and international convergence of cycles. Barras's key motif was that cyclical fluctuations have been an inherent characteristic of economic growth propagated by building investment, with the latter acting as a source of the most volatile cyclical fluctuations in an economy.

Reviews presented by Reed and Wu (2010) and Grover, R. and Grover, C. (2013, 2014) offered alternative perspectives on the subject. In their discussion, Reed and Wu (2010) reviewed literature relating to property cycles in the housing market. Grover and Grover (2013) discussed the exiting body of knowledge on property cycles following the financial crisis of 2008, while in their second review Grover, R. and Grover, C. (2014) discussed and issue of property bubbles.

\section{EXPLORING STUDIES ON THE SUBJECT}

\subsection{Early studies}

The pioneering studies on the subject were particularly concerned with fluctuations in building (especially in residential), which was identified as the largest and the most volatile component of aggregate investments. These studies were inclined towards statistical data analysis and its interpretation, as there was an obvious lack of robust and consistent data. Consequently, early researchers identified both short (around 5 years) and long (around 20 years) building cycles. The prime explanation for the existence of these cycles was a relationship between population growth and the state of the economy. Moreover, building cycles were seen as local phenomena, independent from fluctuations in business.

The first serious discussions and analyses of property cycles emerged during the late nineteenth and early twentieth century. As Gottlieb (1976) and Barras (2009) indicated, German scholars were pioneers of property cycle research. The major object of their investigations was the urban growth of German cities and its impact on residential construction, property market activity and land values. In his general work, Mangoldt (1907) demonstrated the tendency for urban growth to run in long waves in the city of Freiberg. Reich (1912) investigated the residential market in Berlin between 1840 and 1910. Eychmüller (1915) studied the economic development, urban land and building policies of the city of Ulm for the period 1850-1919. In her manuscript, Carthaus (1917) assessed the history of the land crisis in German big cities with a special emphasis on the Greater Berlin. Eisenlohr (1921) in his study discussed 
urban and housing conditions of the city of Mannheim. These studies were subsequently followed by the researchers from other metropolitan areas.

It is considered that in the US research on the subject started in 1933 with Hoyt's publication. In his book Hoyt demonstrated cyclical fluctuations in Chicago property market. The reason for this analysis was the notion that the knowledge of the past movements of property is an indispensable part of any property investment. Results of the statistical analysis suggested that business conditions, commodity price level, the value of money, and particularly rapid increases in population, within short periods of time, were major causes for real estate cycles to occur. On the basis of his research, Hoyt identified relatively long and uncertain building cycles of an average of 18 years. These observations added to Wenzlick's (1933) findings, who identified similar cycles for St. Louise, and Maverick's (1933) observations, who found identical real estate fluctuations for Los Angeles and San Francisco.

In the aftermath of the Great Depression, Newman (1935) further investigated the importance of the subject. The building industry was chosen due to its size and importance to the US economy, and the number of people employed. His research was based on the building activity index, which was comprised from the dollar value of the building permits. The outstanding characteristic of this research was identification of so called 'major cycles', lasting between 15 and 21 years. This coincided with the findings of other contemporary researchers, including Hoyt (1933), Maverick (1933), and Wenzlick (1933). The other major finding of the paper was an existing correlation between building space and population.

A significant contribution towards the research and understanding of building cycles was made by the American economist Clarence D. Long, Jr. In 1936, Long published a study on the building industry of Manhattan in which he identified two types of cycles, i.e. major cycles or 'secondary secular movements' of a period between 15 to 20 years, and minor around 4 years cycles (ibid., p. 184). After this study on a local building market, Long (1939) published an article on national building activity. This study comprised both residential and non-residential building indices of the US for the period between 1856 and 1935. The value-index included twenty seven and the number-index included twenty nine of the most populous cities of the country. Subsequently, Long identified 18-19 years building cycles of both building types.
A year later, Long (1940) published a second major study on the subject, after Hoyt's Chicago case study. As in his previous publications (Long 1936, 1939), Long (1940) emphasised the building industry because of its size (the nation's largest single industry with its strategic importance to the US economy) and the severity of its fluctuations (swings were seen as the widest of any important industry). For his analysis, Long constructed the monthly index of building for the period between 1868 and 1940, which was based on the local figures of building permits. The results of the statistical analysis led the author to identify short building cycles of an average of 4 years duration, and long cycles of around 20 years. These findings were substantiated statistically and cross referenced with other investigations into the subject: Rigglemann (1934, cited in Long 1940) identified 13-22 years long building cycles; Newman (1935) 15-21 years; and Warren and Pearson (1937) - 18 years. However, the major weakness of Long's (ibid.) study was the neglect of the local factors of the building industry. As Singer (1942) indicated, Long (1940) dedicated a major part of his study to the theoretical discussion of 'inducement to invest' in building and its correlation with the general economic concepts, such as interest rate, expectations, building costs, while paying less attention on migration or local property market differences.

An interesting approach was adopted by Walter Isard. He researched the interrelationship between building cycles and transport innovations. In his first paper, Isard (1942a) constructed the theoretical framework of a one-way causal relationship between two sectors based on historical and statistical data analyses. It led the researcher to identify six cycles of building and transport development, and thus to conclude that 'the six building cycles which the United States has experienced from the late 1820's to the early 1930's can be accounted for by various innovations in transport' (ibid., p. 112). In his second paper on the subject, Isard (1942b) investigated movements in transport-building cycles and their existence in strategic economic series, such as investment, population, production, and prices. Isard's analysis demonstrated the existence of highly regular and synchronous transport-building cycles, averaging 17 to 18 years. Consequently, this study led to the construction of the theoretical framework of the one-way causal relationship between building cycles and transport development.

In the UK one of the first studies on building cycles was written by Cairncross (1934). In his 
analysis of the Glasgow building industry for a period from 1870 to 1914 , the author identified building cycles of around 20 years in length. Cairncross stated that housing will 'naturally fluctuate with the number and incomes of potential tenants' (ibid., p. 4). Similarly, Wenzlick (1933) noted that the marriage-rate and migration had a substantial effect on building cycles.

With regard to the research on the subject in the United Kingdom, the same year as Cairncross (1934) published his investigation into Glasgow building industry, Shannon (1934) produced a building index (index of brick production) for England for the period between 1785 and 1849. Statistical analysis of the data led the author to identify the existence of 16 year-long building cycles, which were closely correlated with population growth.

In 1937, Bowley made an investigation into fluctuations of the house-building and trade cycles between 1924 and 1936 for England and Wales. The analysis led to the conclusion that changes in the population was the primary factor influencing the demand for housing. The similar conclusions were draw earlier by Beveridge (1930).

A more robust discussion on the subject was presented by Bowen (1940). In his analysis, Bowen employed three national time series Building Plans Passed, Ministry of Health Returns of Houses Completed, and Ministry of Labour Insured Unemployment Returns for the Building Industry for 1924-1938 period. After he eliminated the population factor, which was considered as the causal element for a long-term demand for building, and applied M. Abram's London and Cambridge Economic Service index, the connection between building activity and general trade cycle has been proved.

Table 1 summarises the key publications on property cycles during this research era. It contains authorship, data and data analysis techniques which were employed by researchers, as well as outcomes of these studies. The following section reviews the key publications produced during the post-war period.

Table 1. Key 'Early era' publications on property cycles

\begin{tabular}{|c|c|c|c|}
\hline Publication & Data employed & Methodology & Results \\
\hline Hoyt (1933) & $\begin{array}{l}\text { Land values; New construction } \\
\text { rate; Lots subdivided; Public } \\
\text { improvements; Population; } \\
\text { Foreclosures; Real estate trans- } \\
\text { fers; Bank clearings; Canal-rail } \\
\text { stock prices; Wholesale com- } \\
\text { modity prices }\end{array}$ & $\begin{array}{l}\text { Data comparison; Turning } \\
\text { point analysis; Time-series } \\
\text { analysis (1830-1933); Visual } \\
\text { data analysis }\end{array}$ & $\begin{array}{l}18 \text { years building cycles; Real } \\
\text { estate cycles may be a passing } \\
\text { phase }\end{array}$ \\
\hline Cairncross (1934) & $\begin{array}{l}\text { House building and demolition } \\
\text { rates; Rents; Site values; Heavy } \\
\text { industry activity; Interest } \\
\text { rates; Population (rate of mar- } \\
\text { riage and immigration) }\end{array}$ & $\begin{array}{l}\text { Data comparison; Turning } \\
\text { point analysis; Time-series } \\
\text { analysis (1870-1914); Visual } \\
\text { data analysis }\end{array}$ & $\begin{array}{l}20 \text { years building cycles; Real } \\
\text { estate cycles have a great cor- } \\
\text { relation with population }\end{array}$ \\
\hline Newman (1935) & $\begin{array}{l}\text { Building permits; Building } \\
\text { costs; Population growth; Bond } \\
\text { yields; Rents; Operating ex- } \\
\text { penses }\end{array}$ & $\begin{array}{l}\text { Time-series analysis (1875- } \\
\text { 1933); Turning point analysis; } \\
\text { Correlation analysis; Index } \\
\text { composition }\end{array}$ & $\begin{array}{l}15-21 \text { years 'major cycles'; } 4-5 \\
\text { years 'minor cycles'; Building } \\
\text { cycles precede business cycles; } \\
\text { Independence between move- } \\
\text { ments of two series; Constant } \\
\text { correlation between building } \\
\text { space and population }\end{array}$ \\
\hline Long (1940) & $\begin{array}{l}\text { Gross capital formation; Total } \\
\text { construction; Building costs; } \\
\text { Income; Interest rates; Build- } \\
\text { ing levels; Population; Taxes; } \\
\text { Housing costs }\end{array}$ & $\begin{array}{l}\text { Time-series analysis (1868- } \\
\text { 1940); Turning point analysis; } \\
\text { descriptive statistics (averages, } \\
\text { deviations, medians); Correla- } \\
\text { tion analysis; Assumption test- } \\
\text { ing; Index composition; Index } \\
\text { smoothing }\end{array}$ & $\begin{array}{l}4 \text { years short building cycles; } \\
20 \text { years long building cycles; } \\
\text { Greater volatility of cycles } \\
\text { in building than in business; } \\
\text { Building cycles precede busi- } \\
\text { ness cycles; Correlation be- } \\
\text { tween long building cycles and } \\
\text { the general business conditions }\end{array}$ \\
\hline Bowen (1940) & $\begin{array}{l}\text { Building plans passed; Returns } \\
\text { of houses completed; Insured } \\
\text { unemployment returns for the } \\
\text { building industry; Savings }\end{array}$ & $\begin{array}{l}\text { Time-series analysis (1924- } \\
\text { 1938); Correlation analysis; } \\
\text { Data comparison; Visual data } \\
\text { analysis; Data smoothing ( } 3 \\
\text { year moving average); Trend } \\
\text { analysis }\end{array}$ & $\begin{array}{l}\text { Correlation between building } \\
\text { an population; A greater role of } \\
\text { building within the economy }\end{array}$ \\
\hline
\end{tabular}




\subsection{Three key post-war studies: Abramowitz (1964), Lewis (1965) and Gottlieb (1976)}

After a flourish of studies and publications on property and building cycles during the 1930's, there was a decline in the volume of research on the subject during the post-war period. As Lewis (1960) and Barras (2009) note, individual studies such as Grebler (1954), Weber (1955), or Cairncross and Weber (1956) were published offering a greater clarity on the subject. The commentators enriched an understanding of the property and building cycles. These studies however mostly resumed the major publications of the 1930's only by adding newer data or expanding statistics of their predecessors.

One of the first attempts to renew the discussion on the subject was Lewis' (1960) empirical study on the dynamics of regional building. According to Lewis, regional building cycles were seen as major elements of the total building cycle mechanism. As he has observed, 'there can be no national building boom without there being at least one local boom, and the justification for a local boom must lie in local need' (ibid., p. 533).

Lewis (1961) discussed the effect of aggregation onto movements through time of different variables. He theorised that aggregation can reverse the duration of lag. Therefore, this aggregation effect was seen as highly important for building.

Lewis (1964) attempted to explain the inverse long cycle of the Atlantic economy. The study was designed to identify the major factors of these long swings between two countries - the UK and the US. The results of the mathematical modelling indicated that housing, population, and, as the author indicated, 'times of good credit' were causal agents of the long cycles (ibid., p. 118). It led the commentator to conclude that favourable conditions for one country were unfavourable to the other.

The inverse cycles were also studied by Cooney (1960), Guttentag (1961), Saul (1962), Vipond (1969) and other researchers. Cooney (1960) statistically demonstrated the inverse correlation of building activity of around twenty years of length in the UK and the US during the nineteenth century. Saul (1962) studied house building of England for a period between 1890 and 1914. He collected statistics on house building from over 100 sources. Statistical data analysis led him to conclude that, although the external factors identified by Cooney (1960) were of significant importance, the investment in housing "was largely determined by causes special to the domestic housing market' (ibid., p. 120). Guttentag (1961) in his study into the US residential construction during the 1946-1959 period demonstrated an inverse cycle between residential construction and business cycle. In contrast, Vipond's (1969: 209) investigation into fluctuations in private house-building in the UK for a period from 1950 to 1966 led to the conclusion that 'private residential building activity exhibited market pro-cyclical tendencies' over the study period.

As Barras (2009) indicated, three major empirical studies - one by Lewis (1965) in the UK, and two by Abramowitz (1964) and Gottlieb (1976) in the US set the culmination of the post-war wave of research on building cycles.

In 1965, Lewis published his major historic survey of British economic growth from 1700 to 1950. Identification of the building cycles of 18 to 20 years of length was one of the central findings of the book. Lewis argued that building cycles were generated by a number of factors, such as production, income, population structure, migration, credit supply, and rent level, their interconnection as well as upon the economic context in which they occur. The impact of exogenous factors, such as war and the level of harvest were also noted. However, two key factors population and credit conditions were particularly emphasised. The importance of credit conditions was also addressed by Fleming (1966). As Fleming observed, 'a building boom will only take place if abundant funds are available to finance it' (ibid., p. 436).

Following a tradition that originated from the National Bureau of Economic Research (NBER), Abramowitz (1964) published one of the major postwar studies on the subject in the US. His analysis of 38 annual time-series identified long waves in the aggregative construction of duration between 15 and 25 years. Uniform long swings were also found in the other major areas of American development, such as population growth, immigration, volume of import, and the railroad. These findings were referred to the earlier publications of Rigglemann (1934) and Long (1940). For his data analysis, Abramowitz first smoothed data series by computing their averages. Then he compared them with the original data. This enabled the researcher to identify long waves within all sectors of construction activity, as well as distinguish them from business cycle fluctuations, and check their correlation with other segments of the economy.

The study by Gottlieb (1976) offered probably the most comprehensive empirical analysis of the 
subject at that time. Gottlieb employed over 200 long time-series on building, finances, demographic and real estate activities of the US, UK, Sweden, France, Australia, Netherlands, Germany, Canada, Italy, and Japan. He then applied the mildest of smoothing procedures used by NBER, i.e. fixed reference-cycle methodology, in order to eliminate the influence of short cyclical fluctuations from the time-series. This procedure enabled him to isolate the long-swing movements and identify their specific turning points. The results of this study showed that both long local and national building cycles were virtually of the same duration, i.e. of around 20 years. As Gottlieb argued, 'local cycles were simply a local phase of a national movement, while the national movement was in turn mainly a coalescence of local cycles' (ibid., p. 9). His analysis also identified the existing correlation between building cycles and demographic changes. As Gottlieb explained, favourable economic conditions encourage or discourage formation of new households, what consequently has a direct effect on the volume of demand for existing and additional dwellings.

Table 2 summarises the key publications of this research period, which includes author, data and data analysis techniques employed and outcomes of these studies. The following section presents the key post-1970s crash studies on property cycles.

\subsection{Post-1970s crash studies}

In this section studies of the last forty years on the property cycles are considered. According to Solomou (1998) and RICS (1999), the 1960s was a period of apparent economic stability. Consequently, it led some commentators, including Abramowitz (1968) and Bronfenbrenner (1969), to question whether cycles were still relevant. However, the crash of the mid 1970s triggered a renewed wave of research on property cycles. In the UK this coincided with the launch of the Investment Property Databank (IPD) Long Run Index running from 1971, which provides reliable property data (RICS 1994; Baum 2001). As Barras (1994) indicated, his personal interest on the subject was first prompted by the 1970s property crash, which led to the publication of several papers including Barras (1983, 1984, and 1987), as well as series of papers commissioned from the Economic and Social Research Council (ESRC) on building cycles in Britain (Barras, Ferguson 1985, 1987a, 1987b).

These early modern property cycle studies were based on the hypothesis that major property cycles are generated by their endogenous forces. The key factor for these cycles to occur was an inherent production lag within the construction industry. The minor cycles were seen as the demand-side phenomenon reacting to changes in business. Particular attention was also placed on the financial

Table 2. Key post-war publications on property cycles

\begin{tabular}{|c|c|c|c|}
\hline Publication & Data employed & Methodology & Results \\
\hline Abramowitz (1964) & $\begin{array}{l}38 \text { series on non-farm resi- } \\
\text { dential, private non-residen- } \\
\text { tial, farm, public and ship } \\
\text { building, and transportation } \\
\text { and public utilities }\end{array}$ & $\begin{array}{l}\text { Data comparison; Time- } \\
\text { series analysis (1870-1955); } \\
\text { Turning point analysis; } \\
\text { Visual data analysis; Data } \\
\text { smoothing (5 and } 10 \text { year } \\
\text { moving average); Amplitude } \\
\text { measurement. }\end{array}$ & $\begin{array}{l}\text { 15-25 years building cycles; } \\
\text { Close interaction between } \\
\text { building and the economy; } \\
\text { Structural change of the US } \\
\text { economy leads to demise of } \\
\text { cycles }\end{array}$ \\
\hline Lewis (1965) & $\begin{array}{l}20 \text { time-series (import/ex- } \\
\text { port, building rate, marriage } \\
\text { rate, bank rate, house prices, } \\
\text { rents, etc.) }\end{array}$ & $\begin{array}{l}\text { Time-series analysis } \\
\text { (1700-1950); Turning point } \\
\text { analysis; Correlation analy- } \\
\text { sis; Index creation (artificial } \\
\text { time-series); Probability } \\
\text { modelling (experiments with } \\
\text { multiplier-accelerator mech- } \\
\text { anism) }\end{array}$ & $\begin{array}{l}\text { 18-20 years building cycles; } \\
\text { Correlation between build- } \\
\text { ing and population and } \\
\text { credit; Building is a function } \\
\text { of the local factors }\end{array}$ \\
\hline Gottlieb (1976) & $\begin{array}{l}\text { Around } 200 \text { long time-series } \\
\text { (building, building costs, } \\
\text { population, land values, etc.) }\end{array}$ & $\begin{array}{l}\text { Time-series analysis (1840s- } \\
\text { 1930s); Comparison/Visual } \\
\text { inspection; Smoothing } \\
\text { (Time-series decomposition/ } \\
\text { Fixed term moving average); } \\
\text { Turning point analysis; Cor- } \\
\text { relation analysis; Data com- } \\
\text { parison; Visual data analy- } \\
\text { sis; Descriptive statistics; } \\
\text { Amplitude measurement }\end{array}$ & $\begin{array}{l}20 \text { years building cycles; } \\
\text { Correlation between build- } \\
\text { ing and population, as well } \\
\text { as local and national cycles }\end{array}$ \\
\hline
\end{tabular}


side of the phenomena. As Barras (2009) indicated, favourable financial conditions fuelled two speculative property booms, one in the early 1970s, another in the late 1980s/early 1990s. The 1974 crash, as commented by Scott and Judge (2000), was the largest property market corrections since the Second World War. As Browne and Case (1992) and FDIC (1997) documented, this property market crash brought the British and the US economies into recession. According to Baum (2001), a growing property portfolio within financial institutions was another factor for this cycle to occur.

Barras (1983: 1) proposed 'a simple theoretical model of the office development cycle' for Britain. He employed an accelerator type model (secondorder difference equation) and, by incorporating the long term production period between building order and its completion, explained how cycles are generated around their equilibrium growth path.

Barras (1984) examined the major characteristics of the London office market. He discussed main factors which governed the growth of London as an international office centre, illustrated the apparently cyclical nature of office development in London, and briefly reviewed development control policies. Finally, he assessed the 1980s development cycle and likely impact of the future development of both office-based activities and information technologies on user demand for London offices in the post 1980s development cycle.

In 1987, Barras made investigation into 'urban development cycles' in Britain, and their correlation with technological changes. First, he identified that long swings of 20-30 years are generated by shorter cycles, i.e. two shorter cycles are generally superimposed by the dominant long swing, causing pronounced building cycles. Building activity was identified as being more prone to cyclical fluctuations than any other investments. Subsequently, he examined the possible trajectory of the British urban development cycle in relation to technological changes, particularity of IT and micro-electronic. Finally, the author assessed 'the likely characteristics and timing of the next wave of urban development in the UK' (ibid., p. 24).

A significant analysis and discussion on the subject was presented by R. Barras and D. Ferguson in their three stage research commissioned from the ESRC. In the first paper, Barras and Ferguson (1985) investigated the detailed chronology of five major building sectors including private industrial, private commercial, private housing, public housing, and other public building. The research was conducted using two sets of time-series: (i) post- war data of new orders of construction and its output in each of five building sectors, which was available from 1957 (annually) and 1958 (quarterly); (ii) and fixed capital formation of building industry from 1856. The authors employed spectral analysis to determine and compare each building series, their cyclical characteristics, and relationships between the cycles, as well as informal turning point analysis to identify the precise chronology of each cycle. Notwithstanding limitations of both methodologies, Barras and Ferguson demonstrated that the UK post-war building experienced 'strong cycles', i.e. 'short cycles' of $4-5$ years, 'major cycles' of 7-9 years, and 'long swings' of 28 years within housing and 19 years long cycles within other building. Short cycles were highly linked to general business cycles, major cycles - to production lags within construction industry and public expenditures, and long swings - to 'major wave of urban development' (ibid., p. 1389).

In a second paper, Barras and Ferguson (1987a) developed a theoretical dynamic model 'suitable for dynamic modelling of these cycles' (ibid., p. 353). The framework of the model incorporated both endogenous (production lag within the industry) and exogenous conditions (variations in economic activity) of the cycles. The theoretical dynamic model was based on Box and Jenkins (1976) approach to modelling ARIMA (autoregressive integrated moving average) processes. The researchers also included an error-correction technique to derive short-run adjustment dynamics and long-run equilibrium relationships between time-series.

In the concluding paper Barras and Ferguson (1987b) presented empirical results of their research - the best possible time-series model for each property type (private sector industrial, commercial and residential). The authors also noted that user activity is an exogenous factor which heavily impacts commercial property. The construction lag, which serves as an endogenous cycle mechanism, was identified as being responsible for a major cycle of a period of 35 quarters.

In the US modern studies continued to be influenced by the NBER. Grebler and Burns (1982) researched short-term post-war cycles in major US construction sectors following established NBER methodology. The data for the study covered the period from 1950 to 1978. This empirical analysis of duration, amplitude and number of cycles led authors to identify six cycles in private residential construction (18 quarters in average), four in private non-residential (29 quarters in average), and four cycles in state and local construction 
(28 quarters in average) as well as relative difference in average amplitude of cycles.

Following literature, the US cycle research in the 1980s paid particular attention to the office market. According to Wheaton (1987), Clapp (1993) and Barras (2009), it was because of a greater expansion of the US office market at that time, and due to high volatility of this property sector. Wheaton (1987) presented one of the key studies. In this research, Wheaton looked at the post-war US office market and revealed recurrent ten years cycles. Wheaton analysed data between 1960 and 1986 of national office employment, building starts and completions, absorption, and vacancy rate. He also compared historic office vacancy rates of ten major US cities and their averages. These results clearly suggested the existence of a 'national office market cycle' (ibid., p. 283).

The dynamics of office markets in the US was further investigated by DiPasquale and Wheaton (1992). In their article, DiPasquale and Wheaton developed a universal equilibrium model of real estate space (rent) and real estate asset (capital). For their research the authors used comparative statistical analysis of a number of macroeconomic indicators, including short-term and long-term interest rates, availability of construction finances, production level, and employment. The developed four-quadrant diagram illustrated important connections within the property sector and between its two markets (space and asset).
Clapp (1993) adopted the equilibrium model proposed by DiPasquale and Wheaton (1992) for his research. Clapp explored two possible models for measuring natural (normal) vacancy rate, which were also used for office market forecasting.

Table 3 summarises the key publications on property cycles which were produced during 1970s research period. It contains the title, data and data analysis techniques employed and outcomes of these studies. The following section presents the key post-1990s crash studies on property cycles.

\subsection{Post 1990s property crash studies}

The 1990s property crisis, which is considered as far greater than that of the 1970 s, led to a renewed discussion on property cycles (Barras 1994; RICS 1994). The severity, international contagion and serious long-term consequence of this crash (Goetzmann, Wachter 2001) led to a renewed discussion on the subject. As Barras (2005: 63) observed, after this crash the same two questions were asked: 'why did it go wrong?' and 'how can we avoid it happening again?' Property professionals and scholars blamed inaccurate data, its analysis and interpretation, and anticipated that things will improve next time (RICS 1994; Barras 2005). Consequently, it prompted a number of important publications on the subject, including Barras (1994), RICS (1994, 1999), Grenadier (1995), McGough and Tsolacos (1995), and Renaud (1995).

Table 3. Key post-1970s crash publications on property cycles

\begin{tabular}{|c|c|c|c|}
\hline Publication & Data employed & Methodology & Results \\
\hline Barras (1983) & $\begin{array}{l}\text { Time-series (new orders, } \\
\text { capital values, construction } \\
\text { costs, returns; inflation, in- } \\
\text { terest rates, GDP) }\end{array}$ & $\begin{array}{l}\text { Time-series analysis } \\
\text { (1956-1980); Mathemat- } \\
\text { ical modelling; Historical } \\
\text { overview; Correlation/ } \\
\text { Regression analysis; } \\
\text { Turning point analysis }\end{array}$ & $\begin{array}{l}\text { Model of the office development } \\
\text { cycle; Clarification of the me- } \\
\text { chanics behind the cycle; Three } \\
\text { crucial parameters - the length } \\
\text { of the delay between new invest- } \\
\text { ment orders and completions, } \\
\text { the adjustment rate and the } \\
\text { depreciation rate; National aver- } \\
\text { age cycle period - 8-10 years }\end{array}$ \\
\hline Barras (1987) & $\begin{array}{l}\text { Time-series of } 5 \text { sectors - } \\
\text { private industrial, commer- } \\
\text { cial and house-building, and } \\
\text { public house-building and } \\
\text { other public building }\end{array}$ & $\begin{array}{l}\text { Time-series analysis } \\
\text { (1958-1983); Time-series } \\
\text { modelling; Spectral } \\
\text { analysis; Turning point } \\
\text { analysis }\end{array}$ & $\begin{array}{l}20-30 \text { years 'urban development } \\
\text { cycles'; Interconnection between } \\
5 \text { year, } 10 \text { year, and } 20 \text { year } \\
\text { cycles; Suggestions for policy } \\
\text { making }\end{array}$ \\
\hline Wheaton (1987) & $\begin{array}{l}\text { Time-series (construction, } \\
\text { completions, office employ- } \\
\text { ment, absorption, vacancy } \\
\text { rate) }\end{array}$ & $\begin{array}{l}\text { Time-series analysis } \\
\text { (1960-1986); Visual data } \\
\text { analysis; Multi-equation } \\
\text { modelling }\end{array}$ & $\begin{array}{l}10 \text { year office cycles; Growing } \\
\text { cycle amplitude over time; } 3 \text { pos- } \\
\text { sible scenarios (forecasts from } \\
1986 \text { to } 1992 \text { ) }\end{array}$ \\
\hline $\begin{array}{l}\text { DiPasquale and Wheaton } \\
\text { (1992) }\end{array}$ & $\begin{array}{l}\text { Interest rates; Construction } \\
\text { finances; Production level; } \\
\text { Employment; GDP; Rents; } \\
\text { Vacancy rates }\end{array}$ & $\begin{array}{l}\text { Comparative statistical } \\
\text { analysis; Time-series } \\
\text { analysis; Multi-equation } \\
\text { modelling }\end{array}$ & $\begin{array}{l}\text { Universal equilibrium model } \\
\text { (four-quadrant diagram) }\end{array}$ \\
\hline
\end{tabular}


The seminal study commissioned by the RICS (1994) looked into fundamentals of the property cycles and investigated both endogenous and exogenous forces that have produced them. Commentators employed post-war economic and property data of Britain for a period between 1962 and 1992. They used a data set on all property total returns compiled by the IPD, and other major indices, such as rental growth, yield movements, construction orders, and property investment. The visual and statistical data analysis identified short 4-5 years 'recurrent but irregular fluctuations in the rate of total return' (ibid., p. 27). Short cycles were also visible within other sectors and areas of British economy. Other findings suggested close timing between economic and property cycles. The development cycle was identified as a subset of the property market which gives most of its idiosyncratic features to the property cycle.

In their second study, RICS (1999) extended the period of the research back to 1921. The visual data analysis confirmed the existence of recurrent, but irregular property cycles. Spectral analysis showed evidence of cycles ranging from 4 to 12 years. The average length of the cycles was 8 years. As the authors indicated, some fuller statistical tests suggested the existence of major cycles of 9 years of duration, and minor cycles of
5 years duration. The analysis of property returns suggested existence of three separate epochs, i.e. interwar period between 1920s and 1930s, which was characterised as being highly volatile but with particularly high returns on property, post-war period through the 1950s and 1960s, which exhibited less volatile property fluctuations, and highly volatile post 1970 s period.

Barras (1994) re-examine the conceptual model of the building cycle proposed in his earlier study (Barras 1983), and assessed whether this model could explain the 1990s property crash. To implement his goal, Barras employed various time series, including GDP, commercial development, bank lending, new building orders, rents, institutional investments, yield, and capital values of a period from 1952 to 1992 . He also identified major forces which generated these cycles. Accordingly, Barras demonstrated that both the 1970s and 1980s property cycles 'were triggered by the same particular combination of conditions in the real economy, the money economy and the property market' (ibid., p. 195). Moreover, it has also been demonstrated that 'different cyclical forces are at work in the occupier market, the development industry and the investment market, sometimes opposing and sometimes reinforcing each other' (ibid., p. 195). Therefore, as Barras stated, a better knowledge of

Table 4. Key post-1990s crash publications on property cycles

\begin{tabular}{|c|c|c|c|}
\hline Publication & Data employed & Methodology & Results \\
\hline Barras (1994) & $\begin{array}{l}\text { GDP; Capital values; Yields; } \\
\text { Investments; Bank lending; } \\
\text { Rents; Commercial develop- } \\
\text { ment }\end{array}$ & $\begin{array}{l}\text { Accelerator type model (second- } \\
\text { order difference equation); Time-se- } \\
\text { ries analysis (1952-1992); Turning } \\
\text { point analysis }\end{array}$ & $\begin{array}{l}\text { Property market is cyclical; } \\
\text { Cycles are of different duration; } \\
\text { They operate on the basis of } \\
\text { demand and supply for building; } \\
\text { Suggestions for policy making; } \\
\text { Predictions for the next decade }\end{array}$ \\
\hline RICS (1994) & $\begin{array}{l}\text { Property returns; Rents; } \\
\text { Yield; Construction; Invest- } \\
\text { ment; GDP; Consumer } \\
\text { spending; Manufacturing } \\
\text { output; Employment; Inter- } \\
\text { est and gilts rates; Inflation }\end{array}$ & $\begin{array}{l}\text { Time-series analysis (1962-1992); } \\
\text { Visual data analysis; Turning point } \\
\text { analysis; Spectral analysis; Simple } \\
\text { regression modelling }\end{array}$ & $\begin{array}{l}4-5 \text { years property cycles; Close } \\
\text { timing with economic cycles; UK } \\
\text { property market is cyclical; UK } \\
\text { property cycles are the product } \\
\text { of economy and its endogenous } \\
\text { (particularly development lag) }\end{array}$ \\
\hline RICS (1999) & $\begin{array}{l}\text { Property returns; Yield; } \\
\text { Rents; Capital growth; GDP; } \\
\text { Building investment; RPI, } \\
\text { Gilts, Equities, Treasury } \\
\text { bills }\end{array}$ & $\begin{array}{l}\text { Time-series analysis (1921-1997); } \\
\text { Turning point analysis; Visual } \\
\text { data analysis; Correlation analysis; } \\
\text { Time-series simulation; Time- } \\
\text { series desmoothing; Filtering (HP } \\
\text { technique); Spectral analysis; } \\
\text { Multivariate time-series regression } \\
\text { with variable additions/deletion; } \\
\text { Long-run cointegration }\end{array}$ & $\begin{array}{l}\text { 4-9 years cycles; Correlation } \\
\text { with the economy; Strong cycli- } \\
\text { cal pattern; Long-run analysis } \\
\text { adds little to the ability to un- } \\
\text { derstand or predict the market }\end{array}$ \\
\hline $\begin{array}{l}\text { McGough and } \\
\text { Tsolacos (1995) }\end{array}$ & $\begin{array}{l}\text { GDP; Employment; Con- } \\
\text { sumer expenditure; Industry } \\
\text { output; Interest rates }\end{array}$ & $\begin{array}{l}\text { Time-series analysis (1980-1994); } \\
\text { Statistical analysis (amplitude - } \\
\text { standard deviation, persistence - } \\
\text { first order autocorrelation, procy- } \\
\text { clicality and countercyclicality - } \\
\text { cross-correlation) }\end{array}$ & $\begin{array}{l}\text { Correlation between GDP, } \\
\text { manufacturing and business out- } \\
\text { put and the office and industrial } \\
\text { property; and between GDP, con- } \\
\text { sumer expenditure and non-food } \\
\text { retail sales and retail property; } \\
\text { Establishment of stylized facts }\end{array}$ \\
\hline
\end{tabular}


the interaction of these underlying forces leads to a greater understanding of the property cycle.

McGough and Tsolacos (1995) identified forces generating UK property development cycles. The methodology they used was adopted from the business cycle modelling. In their statistical analysis the commentators examined various property demand and economic variables for a period between 1980 Q1 and 1994 Q4 quarterly. The raw data was filtered using the Hodrick-Prescott technique. Subsequently, the researchers estimated the major statistical properties of the chosen variables (amplitude, persistence, procyclicality, and countercyclicality). Amplitude was measured by the standard deviation, persistence - by first order autocorrelation, and both procyclicality and countercyclicality - by cross-correlation. The findings indicated existing correlation between property and certain economic indicators. Establishment of 'stylized facts' was the other major finding.

In the US, a significant discussion on the subject was presented by Grenadier (1995), where the author investigated underlying causes of prolonged real estate cycles. He also examined why some types of property are more prone to wavelike movements than others. Accordingly, Grenadier developed a leasing and construction model to explain the recurrence of over-building and stickiness of vacancy rates.

Table 4 summarises the key publications on property cycles which were produced during this research era, containing title, data and data analysis techniques employed and outcomes of these studies. The following section presents the most recent studies on commercial property cycles.

\subsection{Modern studies}

A considerable amount of literature on property cycles was published from the late 1990s. As Barras (2004, 2009) observed, in both the late 1980s and late 1990s property cycles were truly global phenomena, which affected most markets internationally. As a result, property scholars assessed cycles as an international phenomenon, as well as their links with capital markets. According to Barras (2009: 71) 'the inevitable result was the launch of a new and more extensive phase of research on real estate cycles during the 1990s'. An international phenomenon of the property cycles was discussed by Renaud (1995), Pyhrr et al. (1999), Dehesh and Pugh (2000), Pugh and Dehesh (2001), and other researchers. Herring and Wachter (1998), ECB (2000), Davis and Zhu (2004), and Lizieri (2009) were amongst others who investigated links between property cycles and capital markets.

Likewise, property cycle research agenda gained impetus internationally with articles on the subject growing geographically. Researchers inspected cycles in the other mature economies (inter alia, Baum 2001; Rottke et al. 2003) as well as emerging markets (inter alia, Wand et al. 2000; Mera, Renaud 2000; Collyns, Senhadji 2002).

Renaud (1995) investigated the global property cycle for the period between 1985 and 1994, and identified three international and four major domestic factors which generated this cycle. This exploratory survey was based on quantitative data analysis of most of OECD and several NIE countries.

Pyhrr et al. (1999) and Pyhrr et al. (2003) presented with a detailed discussion and synthesis of commentary on real estate cycles research. In the first paper, Pyhrr et al. (1999) discussed a relevant research (mostly conducted by US researchers) and commentary on the subject within a micro-decision-making context. There the authors reviewed microeconomic and macroeconomic as well as practitioner publications on property cycles, discussed basic theory of cycles, their nature and dynamics, types, modelling, and their strategic implications for property market participants.

In the second study, Pyhrr et al. (2003) developed a real estate cycles research framework and classification model of the literature on the subject. Subsequently, they presented an alphabetic list of the publications related to property cycles which were published since 1980s primarily in the US. Their list comprises more than 150 related publications.

Dehesh and Pugh (2000: 1) examined post Bretton-Woods 'Property Cycles in the Global Economy'. The research covered the post-1980s period with a particular emphasis on Asian countries, especially Japan. As the authors have identified, the breakdown of the Bretton-Woods system has placed property in a wider context. As a result, property became an international business, thus under the sway of both its endogenous forces and conditions within the international economy.

In a successive paper on the subject, Pugh and Dehesh (2001) investigated post-1980s property cycles, the role of institutional conditions, and the international interdependence between property and finance. In this comparative evaluative review the authors identified that economic adversities seep into the socio-economic level of the national economies and thus have an impact on finance and property sectors both locally and internationally. 
The internalisation of property markets and global transmission of cyclical instability since the 1990s triggered property professionals and scholars to investigate apparent links between property and financial markets (Barras 2009). The correlations between property cycles and capital markets were analysed by Quigley (1999), ECB (2000), Davis and Zhu (2004), Lizieri (2009), and other researchers. Some of empirical studies on the subject focused particularly on residential property. As Davis and Zhu (2004) observed, this was because of the data available for this type of research. Country-specific studies identified correlation between housing and the economy. Empirical analysis by de Greef and de Haas (2000) demonstrated a relationship between Dutch housing and the mortgage market. In the US, Quigley (1999) studied housing prices and economic conditions. Gerlach and Peng (2003) revealed the existence of a long-run dynamic relationship between house prices and bank lending in Hong Kong.

In their seminal work Fergus and Goodman (1994: 1) assembled and assessed 'a broad range of evidence about the degree to which a 'credit crunch' decreased real estate lending and construction activity in the 1989-92 period'. Consequently in their empirical historical analysis the authors proposed a chronology of the 'credit crunch'. Davis and Zhu (2004) looked at the interconnection between the commercial property market and bank lending from the macroeconomic perspective. For their research, Davis and Zhu catalogued annual data for 17 countries for the period between 1985 and 1995 collected by BIS (Bank for International Settlements). They then developed a reducedform single equation model based on the work of Wheaton (1999) to assess the relationship between banking and commercial property. Cross-country empirical analysis fully demonstrated this correlation. These findings matched the ones proposed by Fergus and Goodman (1994) a decade earlier.

Subsequent research into the internationalisation of the property market, led property analysts and researchers to investigate the dynamics of the property market on a global scale. According to Chen and Mills (2005: 1) 'global real estate investment has become an increasingly important component of efficient, global mixed-asset portfolios'. Researchers including Case et al. (1999), Jackson et al. (2008) and Stevenson et al. (2011) identified the high degree of synchronisation in cycles across international real estate markets. This therefore suggested significant concordance and commonalities across a large number of property markets. Despite the fact that Chen and Mills (2005) argued that economic and property cycles in different

Table 5. Key 'modern' publications on property cycles

\begin{tabular}{|c|c|c|c|}
\hline Publication & Data employed & Methodology & Results \\
\hline $\begin{array}{l}\text { Wheaton et al. } \\
\text { (1997) }\end{array}$ & $\begin{array}{l}\text { Absorption; Rents; New con- } \\
\text { struction orders; Vacancy; } \\
\text { Total and occupied stock; } \\
\text { Interest rates; Office employ- } \\
\text { ment; Construction costs }\end{array}$ & $\begin{array}{l}\text { Time-series analysis (1970- } \\
\text { 1995); Structural economet- } \\
\text { ric modelling; Econometric } \\
\text { outlook (scenario planning) }\end{array}$ & $\begin{array}{l}\text { Employment can explain London office } \\
\text { market movements; London office market } \\
\text { is volatile; Commercial property in Euro- } \\
\text { pean cities is forecastable; Shocks (posi- } \\
\text { tive/negative) generates and 'echo' }\end{array}$ \\
\hline Barras (2005) & $\begin{array}{l}\text { Take-up; Vacancy; Real rent- } \\
\text { al growth; Building starts } \\
\text { and completions }\end{array}$ & $\begin{array}{l}\text { Time-series analysis } \\
\text { (1970-2004); Multi-equation } \\
\text { modelling (series of linear } \\
\text { difference equations and set } \\
\text { of second order linear dif- } \\
\text { ference equations); Building } \\
\text { cycle simulation }\end{array}$ & $\begin{array}{l}\text { Property market is cyclical; Cyclical } \\
\text { fluctuations are generated endogenously } \\
\text { around and equilibrium growth path; The } \\
\text { longer the construction lag, the longer } \\
\text { the cycle period; } 5 \text { key parameters which } \\
\text { determine model behaviour - (i) the } \\
\text { output growth rate; (ii) the depreciation } \\
\text { rate; (iii) the construction lag; (iv) the } \\
\text { combined transmission coefficient; and } \\
\text { (v) demand elasticity }\end{array}$ \\
\hline Barras (2009) & $\begin{array}{l}\text { Output; Take-up; Building } \\
\text { starts; Capital; Vacancy; } \\
\text { Rents }\end{array}$ & $\begin{array}{l}\text { Time-series analysis }(1968- \\
\text { 2006); Model simulation - si- } \\
\text { multaneous equation }\end{array}$ & $\begin{array}{l}6 \text { key parameters which determine model } \\
\text { behaviour - (i) the size of initial displace- } \\
\text { ment; (ii) the construction lag; (iii) the } \\
\text { output growth rate; (iv) the rate of depre- } \\
\text { ciation; (v) the combined transmission } \\
\text { coefficient; (vi)the demand elasticity } \\
\text { The greater the construction lag, the } \\
\text { greater the period of the cycle }\end{array}$ \\
\hline Barkham (2011) & $\begin{array}{l}\text { Stock market indices; Bond } \\
\text { rates; Rents; Yields; Real } \\
\text { estate spreads over bonds; } \\
\text { GDP growth; National and } \\
\text { international output gaps }\end{array}$ & Descriptive statistics & $\begin{array}{l}\text { Indicator assesses long-ranged property } \\
\text { cycle; presents current state of the prop- } \\
\text { erty market relative to its long-term his- } \\
\text { tory }\end{array}$ \\
\hline
\end{tabular}


regions exhibit low levels of correlation, more recent research suggests that real estate markets across the globe and especially across the key office markets such as New York and London are correlated (Stevenson et al. 2011). The relationship between the macro-economy and the property market and the effect of globalisation is well discussed in Barkham (2012).

In order to reflect this dynamics of the international property market, Grosvenor (Barkham 2011) and IPD (2012) created global property market benchmarks. Grosvenor's (ibid.) global office yield composite indicator serves as a benchmark representing property market dynamics on an international scale. This index reflects the current position of the property market globally relative to its long term history. According to Grosvenor, investors can therefore minimise risk, enhance returns and maximise NAV growth, by using this indicator. IPD's Global Annual Property Index reports the market rebalanced returns of the 24 property markets where IPD and its partners operate. The index reflects the dynamics of the real estate market globally.

Table 5 summarises the key 'modern' studies on the subject, containing title, data and data analysis techniques employed and outcomes of these studies. The following section summarises the study and presents the key findings.

\section{SUMMARY}

In reviewing the literature it was found that property cycles have been recorded throughout history (Hakfoort 1992; Barras 2009). However, serious discussions and analyses on the subject emerged only during the early twentieth century. German scholars including Mangoldt (1907) and Eisenlohr (1921) were pioneers of building cycle research. In the US research on the subject started in 1933 with Hoyt's publication on the Chicago real estate cycles. Cairncross (1934) published one of the first studies on UK building cycles. Since then the relevance of the subject has attracted greater attention of scholars, who investigated different aspects of the subject. In the UK, Lewis (1965) published historic survey of British economic growth from 1700 to 1950, Barras (1987) published an extensive study of post-war building, RICS $(1994,1999)$ examined the main elements of the UK property cycles. Subsequently, as Barras (2009) indicated, research into property cycles began to be conducted in private sector consultancies rather than in academia with the purpose of commercial forecasting.
As results of the literature review indicated, the pioneering studies on the subject were particularly concerned with fluctuations in building (especially in residential), which was identified as the largest and probably the most volatile component of aggregate investment. These studies were highly inclined into statistical data analysis and its interpretation, as there was an obvious lack of robust and consistent data. Consequently, early researchers identified both short (around 5 years) and long (around 20 years) building cycles. The prime explanation for the existence of these cycles was a relationship between population growth and the state of the economy. Moreover, building cycles were seen as local phenomena, independent from fluctuations in business.

Early modern property cycle studies in the UK were based on the premise that major property cycles are generated by their endogenous forces, while minor cycles were seen as the demand-side phenomenon, which is reacting to changes in the economy. The key factor for cycles to occur was an inherent production lag of construction industry. Particular attention was also on the financial side of the phenomena. As Barras (2009) indicated, favourable financial conditions fuelled two speculative property booms, one in the early 1970 s, another in the late 1980s, which brought the British economy into recession. According to Baum (2001), a growing property portfolio within financial institutions was also identified as a catalyst for the property cycles in that period. In the US, however, researchers were focused on rent adjustment processes within the property market, rather than on construction lags. As it was noted, American researchers considered exogenous impulses from the wider economy as having greater impact on property cycles. Due to considerable greater elasticity of the supply side of the property market than its demand, developers were prone to overor under-shoot the market equilibrium, thus creating a deficit or surplus of property. Therefore, in order to anticipate the future property market behaviour, sophisticated rent adjustment models were created.

The experience of the 1990s brought new perspectives into property cycles research. These studies underlined a need for a global perspective on property cycles and particularly their correlation with capital markets. As Herring and Watcher (1998), Davis and Zhu (2004) and Barras (2009) observed, ever closer integration of property and financial markets mean that instability in one market can be easily transmitted to another lo- 
cal or national market. Financial engineering and international flows of capital connect both markets. Moreover, an increasing internalisation of the property market and the same macroeconomic environment translate cycles between countries. Consequently, this contagion effect is creating a greater volatility within markets.

\section{CONCLUSION}

The aim of this paper was to provide a chronological literature review on property cycles over a one hundred year period mostly written in the UK and US. As it was noted above, the particular emphasis was on research methods, data and data analysis techniques employed, and outcomes of these studies. The paper was not designed to be a critical review, but rather a catalogue of the studies on the subject. Consequently, it was aimed to provide a guide to the literature on property cycles, put more clarity on the subject as well as help to navigate anyone interested on property cycles throughout a considerable amount of research chronologically.

\section{ACKNOWLEDGEMENTS}

The authors would like to thank anonymous reviewers for their suggestions regarding this manuscript. All views and errors are those of the author. An initial version of this paper was presented at the XI BSV International Conference on Valuation and Investment in Minsk, Belarus 2010.

\section{REFERENCES}

Abramowitz, M. 1964. Evidences of long swings in aggregate construction since the Civil War. New York: National Bureau of Economic Research.

Abramowitz, M. 1968. The passing of the Kuznets Cycle, Economica 35(140): 349-367.

https://doi.org/10.2307/2552345

Barkham, R. 2011. Global Outlook: Grosvenor's research perspective on world real estate markets. London: Grosvenor.

Barkham, R. 2012. Real estate and globalisation. $1^{\text {st }}$ ed. London: Wiley-Blackwell. https://doi.org/10.1002/9781118351642

Barras, R. 1983. A simple theoretical model of the office development cycle, Environment and Planning A 15(10): 1381-1394. https://doi.org/10.1068/a151381

Barras, R. 1984. The office development cycle in London, Land Development Studies 1(1): 35-50. https://doi.org/10.1080/02640828408723866

Barras, R. 1987. Technical change and the urban development cycle, Urban Studies 24(1): 5-30. https://doi.org/10.1080/00420988720080021
Barras, R. 1994. Property and the economic cycle: building cycles revisited, Journal of Property Research 11(3): 183-197. https://doi.org/10.1080/09599919408724116

Barras, R. 2005. A building cycle model for an imperfect world, Journal of Property Research 22(2): 63-96. https://doi.org/10.1080/09599910500453905

Barras, R. 2009. Building cycles: growth and instability (Real estate issues). London: Wiley-Blackwell. https://doi.org/10.1002/9781444310009

Barras, R.; Ferguson, D. 1985. A spectral analysis of building cycles in Britain, Environment and Planning $A$ 17(10): 1369-1391. https://doi.org/10.1068/a171369

Barras, R.; Ferguson, D. 1987a. Dynamic modelling of the building cycle: 1. Theoretical framework, Environment and Planning A 19(3): 353-367. https://doi.org/10.1068/a190353

Barras, R.; Ferguson, D. 1987b. Dynamic modelling of the building cycle: 2. Empirical results, Environment and Planning $A$ 19(4): 493-520. https://doi.org/10.1068/a190493

Baum, A. 2001. Evidence of cycles in European commercial real estate markets - and some hypotheses, in $\mathrm{S}$. J. Brown; C. H. Liu (Eds.). A global perspective on real estate cycles. The New York University Salomon Center Series on Financial Markets and Institutions 6: 103-115.

Beveridge, W. 1930. Unemployment: a problem of industry (1909 and 1930). $3^{\text {rd }}$ ed. Longmans, Green and Company.

Bowen, I. 1940. Building output and the trade cycle (U.K. 1924-38), Oxford Economic Papers 3: 110-130.

Bowley, M. 1937. Fluctuations in house-building and the trade cycle, Review of Economic Studies 4(3): 167-181. https://doi.org/10.2307/2967452

Box, G. E. P.; Jenkins, G. M. 1976. Time series analysis: forecasting and control. Revised Edition. San Francisco: Holden-Day.

Bronfenbrenner, M. 1969. Is the business cycle obsolete? New York: Wiley-Interscience.

Browne, L. E.; Case, K. E. 1992. How the commercial real estate boom undid the banks, in L. E. Browne; E. S. Rosengren (Eds.). Real Estate and the Credit Crunch. Federal Reserve Bank of Boston, Conference Series No. 36: 57-113.

Cairncross, A. K. 1934. The Glasgow building industry (1870-1914), Review of Economic Studies 2(1): 1-17. https://doi.org/10.2307/2967546

Cairncross, A. K.; Weber, B. 1956. Fluctuations in building in Great Britain, 1785-1849, Economic History Review 9(2): 283-297.

Carthaus, V. 1917. Zur geschichte und theorie der grundstückskrisen in Deutschen grosstädten: mit besonderer berücksichtigung von Gross-Berlin. German Edition. University of California Libraries.

Case, B.; Goetzmann, W. N.; Rouwenhorst, K. G. 1999. Global real estate markets: cycles and fundamentals, Yale ICF Working Paper No. 99-03.

Chen, L.; Mills, T. I. 2005. Global real estate investment going mainstream. UBS Real Estate Research. 
Clapp, J. M. 1993. Dynamics of office markets: empirical findings and research issues. AREUEA Monograph Series, no. 1. Washington, D. C.: The Urban Institute Press.

Collyns, C.; Senhadji, A. 2002. Lending booms, real estate bubbles and the Asian crisis. IMF Working Paper No. WP/02/20.

Cooney, E. W. 1960. Long waves in building in the British economy of the nineteenth century, Economic History Review 13(2): 257-269. https://doi.org/10.1111/j.1468-0289.1960.tb02119.x

Davis, E. P.; Zhu, H. 2004. Bank lending and commercial property cycles: some cross-country evidence. BIS Working Papers No. 150.

De Greef, I.; De Haas, R. 2000. Housing prices, bank lending and monetary policy, De Nederlandsche Bank Research Series Supervision Paper No. 31. https://doi.org/10.2139/ssrn.510602

Dehesh, A.; Pugh, C. 2000. Property cycles in a global economy, Urban Studies 37(13): 2581-2602. https://doi.org/10.1080/00420980020080701

DiPasquale, D.; Wheaton, W. C. 1992. The markets for real estate assets and space: a conceptual framework, Real Estate Economics 20(2): 181-198. https://doi.org/10.1111/1540-6229.00579

ECB. 2000. Asset prices and banking stability [online]. Working paper, European Central Bank. Available at: http://www.ecb.int/pub/pdf/other/assetpricesen. pdf [accessed 19 April 2010].

Eisenlohr, R. 1921. Das arbeiter-siedlungswesen der stadt Mannheim. Karlsruhe.

Eychmüller, F. 1915. Grundstücksmarkt und städtische bodenpolitik in Ulm von 1870-1910. Stuttgart, Tübingen.

FDIC. 1997. History of the eighties: lessons for the future. Federal Deposit Insurance Corporation.

Fergus, J.; Goodman, J. 1994. The 1989-92 credit crunch for real estate: a retrospective, Real Estate Economics 22(1): 5-32. https://doi.org/10.1111/1540-6229.00624

Fleming, M. C. 1966. Review. Building cycles and Britain's growth, by Parry J. Lewis, Economic History Review 19(2): 435-436. https://doi.org/10.2307/2592282

Gerlach, S.; Peng, W. 2003. Bank lending and property prices in Hong Kong, Journal of Banking \& Finance 29(2): 461-481. https://doi.org/10.1016/j.jbankfin.2004.05.015

Goetzmann, W. N.; Wachter, S. M. 2001. The global real estate crash: evidence from an international database, in S. J. Brown; C. H. Liu (Eds.). A global perspective on real estate cycles. The New York University Salomon Center Series on Financial Markets and Institutions 6: 5-23. https://doi.org/10.1007/9781-4419-8642-9_2

Gottlieb, M. 1976. Long swings in urban development. New York: National Bureau of Economic Research.

Grebler, L. 1954. Real estate investment experience in New York City, Journal of Finance 9(2): 216-218.

Grebler, L.; Burns, L. S. 1982. Construction cycles in the United States since World War II, Real Estate Economics 10(2): 123-151. https://doi.org/10.1111/15406229.00260
Grenadier, S. R. 1995. The persistence of real estate cycles, Journal of Real Estate Finance and Economics 10(2): 95-119. https://doi.org/10.1007/BF01096984

Grover, R.; Grover, C. 2013. Property cycles, Journal of Property Investment and Finance 31(5): 502-516. https://doi.org/10.1108/JPIF-05-2013-0030

Grover, R.; Grover, C. 2014. Education briefing: property bubbles - a transitory phenomenon, Journal of Property Investment and Finance 32(2): 208-222. https://doi.org/10.1108/JPIF-01-2014-0005

Guttentag, J. M. 1961. The short cycle in residential construction, 1946-59, American Economic Review 51(3): 275-298.

Hakfoort, J. 1992. Property cycles: a review of the literature and some preliminary results from the Dutch office market. Discussion Paper in Property Research No. 8, City University Business School.

Herring, R. J.; Wachter, S. M. 1998. Real estate booms and banking busts: an international perspective. Centre for Financial Institutions, Working Papers No. 99-27.

Hoyt, H. 1933. One hundred years of land values in Chicago. The relationship of the growth of Chicago to the rise in its land values, 1830-1933. The University of Chicago.

IPD. 2012. IPD Global Property Index [online]. Available at: http://www1.ipd.com/Pages/DNNPage.aspx?DestUrl=http\%3a\%2f\%2fwww.ipd. com\%2fsharepoint.aspx $\% 3 f$ TabId\%3d936 [accessed 22 July 2012].

Isard, W. 1942a. Transport development and building cycles, Quarterly Journal of Economics 57(1): 90112. https://doi.org/10.2307/1881814

Isard, W. 1942b. A neglected cycle: the transport-building cycle, Review of Economics and Statistics 24(4): 149-158. https://doi.org/10.2307/1927670

Jackson, C.; Stevenson, S.; Watkins, C. 2008. NY-LON: does a single cross-continental office market exist?, Journal of Property Investment and Finance 14(2): 79-92.

Lewis, P. J. 1960. Building cycles: a regional model and its national setting, Economic Journal 70(279): 519535. https://doi.org/10.2307/2228807

Lewis, P. J. 1961. Aggregation, peaks and troughs, Review of Economic Studies 29(1): 79-84. https://doi.org/10.2307/2296185

Lewis, P. J. 1964. Growth and inverse cycles: a twocountry model, Economic Journal 74(293): 109-118. https://doi.org/10.2307/2228115

Lewis, P. J. 1965. Building cycles and Britain's growth. London: Macmillan.

Lizieri, C. 2009. Towers of capital: office markets and international financial services. $1^{\text {st }}$ ed. Wiley-Blackwell. https://doi.org/10.1002/9781444320909

Long, C. D., Jr. 1936. Seventy years of building cycles in Manhattan, Review of Economics and Statistics 18(4): 183-193. https://doi.org/10.2307/1927877

Long, C. D., Jr. 1939. Long cycles in the building industry, Quarterly Journal of Economics 53(3): 371-403. https://doi.org/10.2307/1884414 
Long, C. D., Jr. 1940. Building cycles and the theory of investment. NJ: Princeton University Press.

Mangoldt, R. V. 1907. Die städtische bodenfrage eine untersuchung über die tatsachen, ursachen, und abhilfe. Vanderhoeck \& Ruprecht.

Maverick, L. A. 1933. Cycles in real estate activity: Los Angeles county, Journal of Land and Public Utility Economics 9(1): 52-56.

https://doi.org/10.2307/3138761

McGough, T.; Tsolacos, S. 1995. Property cycles in the UK: an empirical investigation of the stylized facts, Journal of Property Finance 6(4): 45-62. https://doi.org/10.1108/09588689510104060

Mera, K.; Renaud, B. 2000. Asia's financial crisis and the role of real estate. Routledge.

Newman, W. H. 1935. The building industry and business cycles. Chicago: University of Chicago Press.

Pugh, C.; Dehesh, A. 2001. Theory and explanation in international property cycles since 1980, Property Management 19(4): 265-297. https://doi.org/10.1108/02637470110404092

Pyhrr, S. A.; Born, W. L.; Manning, C. A.; Roulac, S. E. 2003. Project and portfolio management decisions: a framework and body of knowledge model for cycle research, Journal of Real Estate Portfolio Management 9(1): 1-16.

Pyhrr, S. A.; Roulac, S. E.; Born, W. L. 1999. Real estate cycles and their strategic implications for investors and portfolio managers in the global economy, Journal of Real Estate Research 18(1): 7-62.

Quigley, J. M. 1999. A decent home: housing policy in perspective. Berkeley program on housing and urban policy, Working Paper No. W99-007, 53-99.

Reed, R.; Wu, H. 2010. Understanding property cycles in a residential market, Property Management 28(1): 33-46. https://doi.org/10.1108/02637471011017163

Reich, E. 1912. Der wohnungsmarkt in Berlin von 18401910. Duncker und Humblot.

Renaud, B. 1995. The 1985-94 global real estate cycle: its causes and consequences. Policy Research Working Paper Series No. 1452, The World Bank.

RICS. 1993. Understanding the property cycle. Working paper two: a literature review. London: The Royal Institution of Chartered Surveyors.

RICS. 1994. Understanding the property cycle: economic cycles and property cycles. Main Report. London: The Royal Institution of Chartered Surveyors.

RICS. 1999. The UK property cycle - a history from 1921 to 1997: an analysis of property cycles in the United Kingdom from 1921 to 1997. London: The Royal Institution of Chartered Surveyors.

Rigglemann, J. R. 1934. Variations in building activity in United States cities: PhD Thesis. Baltimore: Johns Hopkins University.

Rottke, N.; Wernecke, M. 2002. Real estate cycles in Germany - causes, empirical analysis and recommendations for the management decision process, in Proceedings of the $8^{\text {th }}$ Conference of the Pacific Rim Real Estate Society, 21-23 January 2002, Christchurch, New Zealand.
Rottke, N.; Wernecke, M.; Schwartz, A. Jr. 2003. Real estate cycles in Germany - causes, empirical analysis and recommendations for the management decision process, Journal of Real Estate Literature 11(3): 325-346.

Roulac, S. E.; Pyhrr, S.; Kämpf-Dern, A.; Pfnür, A. 2013. Is there a market cycle in market cycles research?, in Proceedings of the $29^{\text {th }}$ Annual Conference of the American Real Estate Society, 9-13 April 2013, Kohala Coast, Big Island of Hawaii.

Saul, S. B. 1962. House building in England 1890-1914, Economic History Review 15(1): 119-137. https://doi.org/10.2307/2593293

Scott, P.; Judge, G. 2000. Cycles and steps in British commercial property values, Applied Economics 32(10): 1287-1297. https://doi.org/10.1080/000368400404443

Shannon, H. A. 1934. Bricks - a trade index, 1785-1849, Economica 1(3): 300-318. https://doi.org/10.2307/2548806

Singer, H. W. 1942. Review. Building cycles and the theory of investment, by Clarence D. Long, Jr., Economic Journal 52(205): 98-99. https://doi.org/10.2307/2225720

Solomou, S. 1998. Economic cycles: long cycles and business cycles since 1870. Manchester: Manchester University Press.

Stevenson, S.; Akimov, A.; Hutson, E.; Krystalogianni, A. 2011. Concordance in global office market cycles. Working Papers in Real Estate \& Planning 18/11, Henley Business School, University of Reading.

Vipond, M. J. 1969. Fluctuations in private housebuilding in Great Britain, 1950-1966, Scottish Journal of Political Economy 16(2): 196-211.

Wand, K.; Zhou, Y.; Chan, S. H.; Chau, K. W. 2000. Over-confidence and cycles in real estate markets: cases in Hong Kong and Asia, International Real Estate Review 3(1): 93-108.

Warren, J. F.; Pearson, F. A. 1937. World prices and the building industry - index numbers of prices of 40 basic commodities for 14 countries in currency and gold, and material on the building industry. J. Wiley \& Sons, Inc.

Weber, B. 1955. A new index of residential construction and long cycles in house-building in Great Britain, 1838-1950, Scottish Journal of Political Economy 2(1): 105-128. https://doi.org/10.1111/j.1467-9485.1955. tb00721.x

Wenzlick, R. 1933. The problem of analyzing local real estate cycles, Journal of the American Statistical Association 28(181): 201-206.

https://doi.org/10.2307/2282243

Wheaton, C. W. 1987. The cyclical behaviour of the national office market, Real Estate Economics 15(4): 281-299. https://doi.org/10.1111/1540-6229.00433

Wheaton, C. W. 1999. Real estate "cycles": some fundamentals, Real Estate Economics 27(2): 209-230. https://doi.org/10.1111/1540-6229.00772

Wheaton, C. W.; Torto, R. G.; Evans, P. 1997. The cyclic behavior of the Greater London office market, Journal of Real Estate Finance and Economics 15(1): 77-92. https://doi.org/10.1023/A:1007701422238 